\title{
Comparison the Biodegradation Efficiency of Cypermethrin by Pseudomonas aeruginosa and Enterobactercloacae
}

\author{
Mustafa Hamza AlMamoory ${ }^{1}$, Ithar Kamil Al-Mayaly ${ }^{2}$ \\ Department of Biology, University of Baghdad, College of Science, Baghdad, Iraq
}

\begin{abstract}
Two local bacterial isolates were isolated from agriculture soil contaminated with cypermethrin from AlAbaeje village in Baghdad city,Iraq. Primary screening was done to test bacterial ability to growth and resistance to cypermethrin by using nutrient agar plates containing $500 \mathrm{mg} \mathrm{L} \mathrm{L}^{-1}$ cypermethrin as a sole source of carbon and energy, and incubation at $37^{\circ} \mathrm{C}$ for 72 hours. Secondary screening results showed that these two bacterial isolates have the ability to grow and resistance cypermethrin concentration till 3600 mg $L^{-1}$ in solid MMSM.In lab experiment and under optimal conditions, cypermethrin biodegradation was measured by using FTIR and GC-MS analysis.The results shown that E.cloacae was the best isolate for degrading cypermethrin with percentage $94 \%$ while $P$. aeruginosa with degrading percentage $88 \%$.
\end{abstract}

Keywords: Biodegradation, Cypermethrin, FTIR, GC-MS

\section{Introductions}

Pyrethroids insecticides are a class of lipophilic esters, with an alcohol and an acid moiety. Although less toxic and persistent than other groups of insecticides, they can still represent a problem. Pyrethroids display high affinity to $\mathrm{Na}+$ channels and its binding to these channels causes a prolonged channel opening that may result in a complete depolarization of the cell membrane thus blocking neuronal activity[1]. The most widely used synthetic pyrethroids include permethrin, cypermethrin and deltamethrin. Cypermethrin agricultural products can be applied at various stages of crop development [2].The use of cypermethrin has increased sharply especially in recent years with the restrictions or eliminations of highly toxic organophosphate pesticides, and it has become one of the dominant insecticides among retail sales to consumers [3]. Cypermethrin has an extremely high toxicity to the aquatic environment with concentrations as low as $10 \mu \mathrm{gL}^{-1}$, destroying aquatic invertebrate life [4].[5]reported that cypermethrin was found to have carcinogenic activity in both sexes of Swiss albino mice. Pyrethroids are responsible for respiratory effects, immunological or lymphoreticular effects, neurological effects, gastrointestinal effects, hematological effects and even cause death to the human being [6].Cypermethrin persistence in environment varies from 14.6 to 76.2 days (half-life) depending on physicochemical properties of soil [7]. Microbial activity in soil also plays vital role in determining the fate and behavior of cypermethrin in soil.

Looking into the facts of toxicity and persistency of this pesticide, it is urgently required to develop some strategiesto eliminate or detoxify cypermethrin and its metabolites from the environment. The biological degradation; involves the use of effective microorganism to degrade the complex pesticide into simple inorganic chemicals [8]. Moreover, this technology is less hazardous, environmentally friendly and economically viable and socially acceptable [9]. The native soil microbial consortia are superior and effective consortia for microbial degradation of pesticide than the non-native strains. Because, the native strains grow very good and have advanced adaptability in particular geographical region [10].native microorganisms are highly adaptable and have the capability to degrade the recalcitrant compounds through evolution of new genes, which encode enzymes that can use these compounds as their primary substrates [11].

Several bacterial strains such as Pseudomonas aeruginosa[12], Streptomyces sp. [13], Stenotrophomonas sp. [14] and Serratiamarcescens [15] have been reported to degrade pyrethroid pesticides. The aims of current study, shown the efficiency and different in byproducts produced from biodegradation of cypermethrin by Pseudomonasaeruginosa and Enterobacter cloacae.

\section{Materials and Methods}

\section{Chemicals and Media}

Commercial grade cypermethrin $\left(10 \mathrm{~g} \mathrm{~L}^{-1}\right.$, Bharat Insecticides Limited, India) was purchased from agricultural chemical dealers anddissolved in acetone to make a stock of $1000 \mathrm{mg}$ $\mathrm{L}^{-1}$. Stock solution was filter sterilized and kept in refrigerator for use. Modified Mineral Salt Media, Nutrient agar, Nutrient broth ( $\mathrm{pH} 7)$ were used for the isolation and cultivation of pesticide degrading bacterial strains according to [16].

Screening and isolation of cypermethrin degrading bacteria

Soil samples were collected from different sites of agriculture soil contaminated with cypermethrin from AlAbaeje village in Baghdad city, Iraq. The samples were collected randomly from the superficial layer of soil (10-20 $\mathrm{cm}$ in depth), these fields were already sprayed with cypermethrin for past few years. These soil samples were used for the isolation of cypermethrin-degrading bacteria. 10 $\mathrm{g}$ of soil samples were added to $150 \mathrm{ml}$ MMSM supplemented with $50 \mathrm{mg} \mathrm{L}$ L $^{-1}$ cypermethrin in $250 \mathrm{~mL}$ Erlenmeyer flasks, and incubation was carried out at 150 $\mathrm{rpm}$ and $30{ }^{\circ} \mathrm{C}$ for five days [17]. After dilution, one $\mathrm{ml}$ of soil suspension $\left(10^{-1}, 10^{-3}, 10^{-5}\right.$ and $\left.10^{-7}\right)$ was inoculated in

\section{Volume 6 Issue 12, December 2017}




\section{International Journal of Science and Research (IJSR) \\ ISSN (Online): 2319-7064}

Index Copernicus Value (2016): 79.57 | Impact Factor (2015): 6.391

nutrient agar plates supplemented with $50 \mathrm{mg} \mathrm{L}$ ${ }^{1}$ cypermethrin[7], after 3 days of incubation, the discrete bacterial colonies were purified by repeated inoculating them on plates containing nutrients agar.Cypermethrin degrading bacterial cultures were screened from the isolated pure bacterial cultures by:

1) Primary screening by growing themon nutrient agar plates containing $500 \mathrm{mg} \mathrm{L}^{-1}$ cypermethrin as a sole source of carbon and energy as described by [13].

2) Secondary screening by growing them on solid modified mineral salt media containing cypermethrin as sole source of carbon and energy at different concentration ranging from $\left(600-3600 \mathrm{mg} \mathrm{L}^{-1}\right)$ and incubated at $37{ }^{\circ} \mathrm{C}$ for $24-48 \mathrm{~h}$ The growth of bacterial isolates was examined according to formation of clear zones around the colonies [18].

Identification of cypermethrin degrading bacterial strain The colonies developed on nutrient agar were studied in terms of their shape, colour, odour and their margin, also microscopic examination was achieved for G-stained slides to characterize G-negative bacteria from others. VITEK 2 compact device (Biomerienx, France) was only used to identify the isolates[19,20]. Identification with the VITEK-2 compact system was performed using a Gram Negative (GN) card according to the Manufacturer's instructions [21]. The results were computerized and recorded by the vitek software after the bacterial suspension was loaded in the vitek cards.

\section{Determination of optimum growth conditions}

\section{Optimum pH and Temperature}

Overnight bacterial isolate $(2 \%)$ with $(\mathrm{OD}=0.5)$ were seeded into the $250 \mathrm{ml}$ Erlenmeyer flasks containing modified mineral salt medium $(100 \mathrm{ml})$ supplemented with $100 \mathrm{mg} \mathrm{l}^{-1}$ of cypermethrin. The $\mathrm{pH}$ values of the medium were adjusted to a series of 5,7 and 9. Three sets of flasks were used each having the unique value of $\mathrm{pH}$. Flasks was inoculated in duplicates in a shaker incubator (160 rpm) at $25,30,35,40{ }^{\circ} \mathrm{C}$ for 8 days, the growth of bacterial isolate was observed by measuring Optical Density (absorbance) at $600 \mathrm{~nm}$ in spectrophotometer after culturing for zero time, first, third, fifth and eighth day, respectively [22].

\section{Optimum incubation period}

After determine optimum $\mathrm{pH}$ and temperature the best incubation period for each isolate determine by inoculated $2 \%$ with $(\mathrm{OD}=0.5)$ overnight bacterial isolate in Erlenmeyer flask $(250 \mathrm{ml})$ containing $100 \mathrm{ml}$ of modified mineral salts medium, was adjusted to $\mathrm{pH} 7$ and autoclaved at $121^{\circ} \mathrm{C}$ for $15 \mathrm{~min}$, then supplemented with $100 \mathrm{mg} \mathrm{L}^{-1}$ of cypermethrin. The flasks were incubated in a shaker incubator $(160 \mathrm{rpm})$ at $30^{\circ} \mathrm{C}$ for different periods $(1,3,5,8,10,12,14,16$ days). Experiment carried out in duplicate and the growth of bacterial isolate was observed by measuring Optical Density at $600 \mathrm{~nm}$ in spectrophotometer [23].

\section{Biodegradation Experiment}

Erlenmeyer flasks $(250 \mathrm{ml})$ containing $100 \mathrm{ml}$ of the liquid modified mineral salts medium, the $\mathrm{pH}$ was adjusted to 7 and autoclaved at $121^{\circ} \mathrm{C}$ for $15 \mathrm{~min}$, supplement with $100 \mathrm{mg}$ $\mathrm{L}^{-1}$ of cypermethrin. The flasks were inoculated separately with $2 \%(\mathrm{OD}=0.5)$ from the selected isolates taken from the overnight cultures (one isolate for each flask) [24].

An experiment carried out in duplicate. The flasks were incubated in a shaker incubator with $160 \mathrm{rpm}$ at $30^{\circ} \mathrm{C}$ for 14 days. After the incubation period, $5 \mathrm{ml}$ of broth was taken for extraction and analysis of cypermethrin residues according to[25]. Extracted liquid was taken in eppendorff tube and stored at $-20^{\circ} \mathrm{C}$ till analysed by FTIR and GC-MS.

\section{Determination of Cypermethrin Residual}

Residual analysis of cypermethrin in media was performed according to [25]. Residual pesticide was extracted by adding $5 \mathrm{ml}$ of culture broth to $20 \mathrm{ml}$ of acetone in a flask. The mixture was filtered using Buchner funnel after shaking for $1 \mathrm{~h}$ and the obtained residue was filtered again by Millipore filter unit $8 \mu \mathrm{m}$ (Whatman Grade 540 Quantitative Filter Paper, Hardened Ashless) after washing thoroughly with $10 \mathrm{ml}$ acetone. Filtrate was collected in a round-bottom flask [24]. The cypermethrin content was detected using GCmass and the percentage of cypermethrin biodegradation was measured according to the following equation [26]:

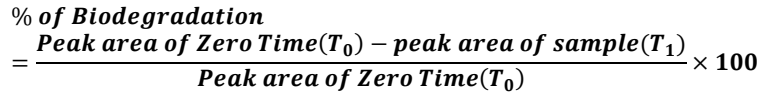

\section{By FTIR}

The use of Fourier transform infrared (FTIR) spectroscopy provided additional information to aid the interpretation of the biodegradation process. Analysis was carried out in labs of chemistry department/college of science/University of Baghdad. Measurement were performed using a Shimadzu FTIR-8400 S using $\mathrm{KBr}$ discs containing $2 \mathrm{ml}$ of test samples which are prepare performed according [25]. Ten scans were taken for each sample in the range 400 to $4000 \mathrm{~cm}^{-1}$.the measure FTIR for samples done on zero time and fourteenth day of experiment [27].

\section{By GC-MS}

Cypermethrin compounds in media were determined using gas chromatography - mass spectrometry (GC-mass). All analysis was carried out in labs of the environment and water directorate/ ministry of Science and Technology.

\section{Statistical analysis}

Least significant difference (LSD) was carried out using statistical package for social sciences (SPSS, Version 17.0). Analysis of variance (ANOVA), P - values, tests of significance, was carried out at $95 \%$ level of confidence using statistical package for social sciences. P - Values[* $(\mathrm{P} \leq 0.05)$ ] were used to determine the significance levels between various treatments and data obtained during the experimental study [28].

\section{Results and Discussion}

\section{Isolation and characterization of cypermethrin degrading bacteria \\ In the present study two isolatesPseudomonas aeruginosa and Enterobacter cloacaewere only selected due to their ability to utilize cypermethrin as a carbon source. Characteristic of Bacterial colonies growing on nutrient agar plates give in table 1 .}

\section{Volume 6 Issue 12, December 2017}




\section{International Journal of Science and Research (IJSR) ISSN (Online): 2319-7064 \\ Index Copernicus Value (2016): 79.57 | Impact Factor (2015): 6.391}

Table 1: Morphological characteristic, Gram stain, ID and probability value of bacterial isolates.

\begin{tabular}{|c|c|c|c|c|c|c|}
\hline Isolates $\mathrm{N}_{0}$ & $\begin{array}{l}\text { Colong } \\
\text { shape }\end{array}$ & $\begin{array}{l}\text { Colony } \\
\text { color }\end{array}$ & $\begin{array}{l}\text { Cell } \\
\text { shape }\end{array}$ & $\begin{array}{l}\text { Gnam } \\
\text { stain }\end{array}$ & $\begin{array}{l}\text { ID of isolate } \\
\text { By Viek ? } \\
\text { compoct }\end{array}$ & $\begin{array}{c}\text { pnobabianing } \\
\text { value }\end{array}$ \\
\hline 1 & $\begin{array}{l}\text { Smooth } \\
\text { flat }\end{array}$ & yellow & Rod & Negative & $\begin{array}{c}\text { Enterobacter } \\
\text { cloacae }\end{array}$ & $99 \%$ \\
\hline 2 & $\begin{array}{l}\text { Semooth } \\
\text { cosvex }\end{array}$ & green & Rod & Negative & $\begin{array}{c}\text { Pessidomonar } \\
\text { aenginosa }\end{array}$ & $99 \%$ \\
\hline
\end{tabular}

According to VITEK 2 compact result the dominate isolate in soil contaminated with cypermethrin was Pseudomonas aeruginosa about $87.5 \%$ while Enterobacter cloacae present in $12.5 \%$.

\section{Optimization of growth conditions}

\section{Optimum pH and Temperature}

Effect of $\mathrm{pH}$ and Temperature on growth of Pseudomonas aeruginosa

The results in Table 2 explains that there are significant difference $(\mathrm{p}<0.05)$ of bacterial growth at different $\mathrm{pH}$ and temperature degrees. Under $25{ }^{\circ} \mathrm{C}, 30{ }^{\circ} \mathrm{C}, 35^{\circ} \mathrm{C}$ and $40{ }^{\circ} \mathrm{C}$ the best and significant means bacterial growth recorded at pH 7 were $0.218,0.360,0.224$ and $0.133 \mathrm{~nm}$ respectively. Also under $\mathrm{pH} 5, \mathrm{pH} 7$ and $\mathrm{pH} 9$ the best and significant means of bacterial growth recorded at $30^{\circ} \mathrm{C}$ as $0.205,0.360$ and $0.114 \mathrm{~nm}$ respectively. The highest mean value for P.aerogenosa growth recorded at $30^{\circ} \mathrm{C}$ and $\mathrm{pH} 7$ was 0.360 $\mathrm{nm}$, while lowest mean value recorded at $35^{\circ} \mathrm{C}$ and $\mathrm{pH} 9$ was $0.022 \mathrm{~nm}$. As shown in fig 2 .

Table 2: Mean value of Pseudomonas aeruginosa growth at different $\mathrm{pH}$ and temperature value after 8 days of incubation

\begin{tabular}{|c|c|c|c|c|}
\hline Temp. & pH 5 & $\mathrm{pH}$ & $\mathrm{pH} \mathrm{9}$ & LSD $\leq 0.05$ \\
\hline $25^{\circ} \mathrm{C}$ & $\begin{array}{c}0.129 \pm \\
0.046 \mathrm{Bb}\end{array}$ & $\begin{array}{c}0.218 \\
\pm 0.062 \mathrm{Ab}\end{array}$ & $\begin{array}{c}0.100 \pm \\
0.047 \mathrm{Bab}\end{array}$ & 0.064 \\
\hline $30^{\circ} \mathrm{C}$ & $\begin{array}{c}0.205 \pm \\
0.051 \mathrm{Ba}\end{array}$ & $\begin{array}{c}0.360 \pm \\
0.098 \mathrm{Aa}\end{array}$ & $\begin{array}{c}0.114 \pm \\
0.114 \mathrm{Ba}\end{array}$ & 0.126 \\
\hline $35^{\circ} \mathrm{C}$ & $\begin{array}{c}0.112 \pm \\
0.058 \mathrm{Bb}\end{array}$ & $\begin{array}{c}0.224 \pm \\
0.100 \mathrm{Ab}\end{array}$ & $\begin{array}{c}0.022 \pm \\
0.016 \mathrm{Bc}\end{array}$ & 0.073 \\
\hline $40^{\circ} \mathrm{C}$ & $\begin{array}{c}0.059 \pm \\
0.021 \mathrm{Bb}\end{array}$ & $\begin{array}{c}0.113 \pm \\
0.039 \mathrm{Ab}\end{array}$ & $\begin{array}{c}0.032 \pm \\
0.032 \mathrm{Bb}\end{array}$ & 0.035 \\
\hline $\mathrm{LSD} \leq 0.05$ & 0.074 & 0.122 & 0.070 & \\
\hline
\end{tabular}

*Uppercase refer to comparison between means with same raw, lowercase refer to comparison between means with same column and similar characters refer to non-significant difference
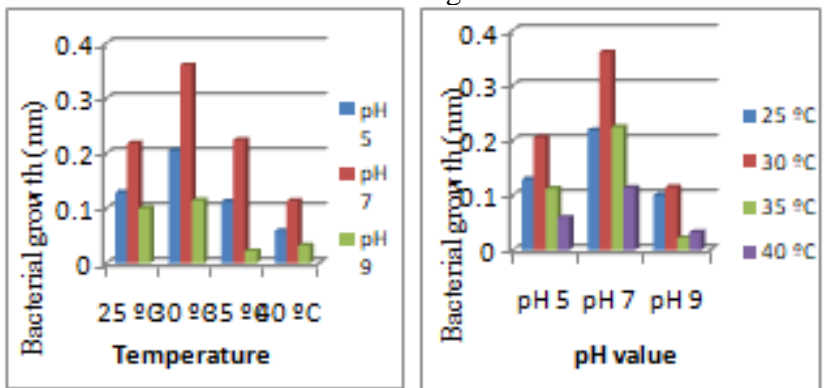

Figure 2: Mean value of Pseudomonas aeruginosa growth at different $\mathrm{pH}$ and temperature value after 8 days of incubation.
Effect of pH and Temperature on growth of Enterobacter cloacae

The results in Table 3 present that there are significant difference $(\mathrm{p}<0.05)$ in bacterial growth at different $\mathrm{pH}$ and temperature degrees. Under $25^{\circ} \mathrm{C}, 30^{\circ} \mathrm{C}$ and $35^{\circ} \mathrm{C}$ the best and significant means bacterial growth recorded at $\mathrm{pH} 7$ were $0.186,0.345$, and $0.155 \mathrm{~nm}$, respectively. While no significant difference was observe at $40{ }^{\circ} \mathrm{C}$ at pH 5, 7 and 9 . Also at $\mathrm{pH} 5, \mathrm{pH} 7$ and $\mathrm{pH} 9$ the best and significant means of bacterial growth recorded at $30{ }^{\circ} \mathrm{C}$ were $0.223,0.345$ and $0.225 \mathrm{~nm}$ respectively. The highest mean value $0.345 \mathrm{~nm}$ for Enterobacter cloacae growth was recorded at $30{ }^{\circ} \mathrm{C}$ and $\mathrm{pH}$ 7 , while lowest mean value $0.036 \mathrm{~nm}$ was recorded at $35^{\circ} \mathrm{C}$ and $\mathrm{pH}$ 9. As shown in fig 3.

Table 3: Mean value of E. cloacae growth at different $\mathrm{pH}$ and temperature value after 8 days of incubation

\begin{tabular}{|c|c|c|c|c|}
\hline Temp. & $p H 5$ & $p H 7$ & $p H 9$ & $L S D \leq 0.05$ \\
\hline $25^{\circ} \mathrm{C}$ & $\begin{array}{c}0.071 \pm \\
0.008 \mathrm{Bb}\end{array}$ & $\begin{array}{c}0.186 \pm \\
0.114 \mathrm{Ab}\end{array}$ & $\begin{array}{c}0.082 \pm \\
0.044 \mathrm{Bb}\end{array}$ & 0.053 \\
\hline $30^{\circ} \mathrm{C}$ & $\begin{array}{c}0.223 \pm \\
0.053 \mathrm{Ba}\end{array}$ & $\begin{array}{c}0.345 \pm \\
0.093 \mathrm{Aa}\end{array}$ & $\begin{array}{c}0.225 \pm \\
0.043 \mathrm{Ba}\end{array}$ & 0.113 \\
\hline $35^{\circ} \mathrm{C}$ & $\begin{array}{c}0.130 \pm \\
0.073 \mathrm{ABb}\end{array}$ & $\begin{array}{c}0.155 \pm \\
0.089 \mathrm{Ab}\end{array}$ & $\begin{array}{c}0.036 \pm \\
0.044 \mathrm{Bb}\end{array}$ & 0.107 \\
\hline $40^{\circ} \mathrm{C}$ & $\begin{array}{c}0.115 \pm \\
0.011 \mathrm{Ab}\end{array}$ & $\begin{array}{c}0.086 \pm \\
0.071 \mathrm{Ab}\end{array}$ & $\begin{array}{c}0.055 \pm \\
0.021 \mathrm{Ab}\end{array}$ & 0.114 \\
\hline$L S D \leq 0.05$ & 0.070 & 0.143 & 0.055 & \\
\hline
\end{tabular}

*Uppercase refer to comparison between means with same raw, lowercase refer to comparison between means with same column and similar characters refer to non-significant difference
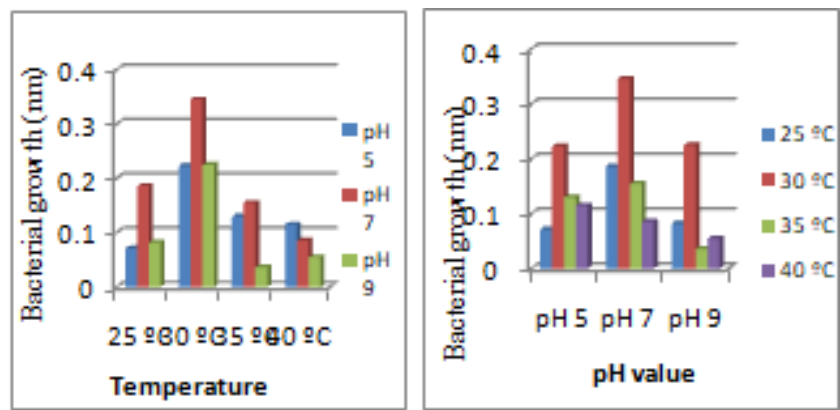

Figure 2: Mean value of E. cloacae growth at different $\mathrm{pH}$ and temperature value after 8 days of incubation.

So the $\mathrm{pH} 7$ is optimum $\mathrm{pH}$ for growth of two selected bacterial isolates in MMSM contain cypermethrin, this finding is supported by [32], who reported that isolated Pseudomonas strain can grow and retain their degradation ability in a wide range of $\mathrm{pH}$ with optimum growth at $\mathrm{pH}$ around 7. Regarding temperature $30^{\circ} \mathrm{C}$ is optimum for growths of two selected bacteria isolate. During Cypermethrin degradation, the direct correlation was found between temperature and microbial activity, significant removal occurred when biosimulator was operated at $28-30$ ${ }^{\circ} \mathrm{C}$ [29].

Effect of Incubation period on growth and biodegradation

The results in table 4 showed significant difference $(p<0.05)$ among means of bacterial growths for different incubation periods. The two selected bacterial isolates had highest and significant growth after 10 days of incubation.From day 1 to

Volume 6 Issue 12, December 2017 


\section{International Journal of Science and Research (IJSR) \\ ISSN (Online): 2319-7064 \\ Index Copernicus Value (2016): 79.57 | Impact Factor (2015): 6.391}

day 10 there are gradually increase in growth rate of two selected bacterial isolates after 10 days of incubation the growth start to decrease. The highest mean growth value 0.457 and 0.517 recoded for E.cloacae and P. aeruginosa respectively. Also there are significant difference $(\mathrm{p}<0.05)$ between mean growth of two selected isolates within same day and this difference start significantly after 3 days of incubation.. As shown in fig 4.

Table 4: Mean values \pm SD of Bacterial growth at $600 \mathrm{~nm}$ at different incubation periods, and LSD value incubation

\begin{tabular}{|c|c|c|c|}
\hline \multirow{2}{*}{$\begin{array}{c}\text { Incubation } \\
\text { period Days }\end{array}$} & \multicolumn{2}{|c|}{ Mean \pm SD of bacterial growth } & \multirow{2}{*}{ LSD $\leq 0.05$} \\
\cline { 2 - 4 } & P. aerogenosa & E. cloacae & \\
\hline First Day & $0.207 \pm 0.015 \mathrm{Ag}$ & $0.227 \pm 0.023 \mathrm{Ae}$ & 0.036 \\
\hline Third Day & $0.340 \pm 0.011 \mathrm{Af}$ & $0.317 \pm 0.015 \mathrm{Bd}$ & 0.025 \\
\hline Fifth Day & $0.367 \pm 0.015 \mathrm{Ae}$ & $0.370 \pm 0.026 \mathrm{Ac}$ & 0.038 \\
\hline Eighth Day & $0.487 \pm 0.006 \mathrm{Ab}$ & $0.443 \pm 0.006 \mathrm{Ba}$ & 0.015 \\
\hline Tenth Day & $0.517 \pm 0.006 \mathrm{Aa}$ & $0.457 \pm 0.015 \mathrm{Ba}$ & 0.026 \\
\hline Twelfth Day & $0.470 \pm 0.010 \mathrm{Ab}$ & $0.407 \pm 0.015 \mathrm{Bb}$ & 0.024 \\
\hline Fourteenth Day & $0.437 \pm 0.006 \mathrm{Ac}$ & $0.367 \pm 0.015 \mathrm{Bc}$ & 0.031 \\
\hline Sixteenth Day & $0.400 \pm 0.010 \mathrm{Ad}$ & $0.327 \pm 0.015 \mathrm{Bd}$ & 0.041 \\
\hline LSD $\leq 0.05$ & 0.018 & 0.030 & \\
\hline
\end{tabular}

*Uppercase refer to comparison between means with same raw, lowercase refer to comparison between means with same column and similar characters refer to non-significant difference

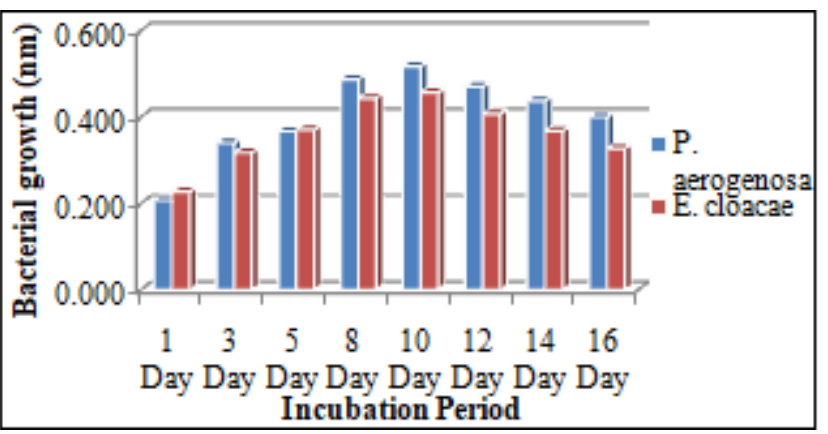

Figure 4: Mean value of Bacterial growth at different incubationperiods.

It is well known the increasing of incubation period which results in to increase viable counts [30] particularly on media with low nutrient concentrations, and due to depletion of contaminate concentration and produce of intermediates compounds and metabolic products that result in decrease the $\mathrm{pH}$ of media and then decreases the growth of bacteria [31].

\section{Biodegradation of Cypermethrin}

\section{FTIR analysis of biodegraded cypermethrin}

Between 600 and $1800 \mathrm{~cm}^{-1}$ In this region, the main absorption bands of cypermethrin are assigned to the carbonyl asymmetric stretching (1720- $1740 \mathrm{~cm}-1), \mathrm{C}=\mathrm{C}$ stretching of the aromatic rings (1450 and $\left.1600 \mathrm{~cm}^{-1}\right), \mathrm{CH} 2$ deformation in R-CH2-CN structure (1400-1450 $\left.\mathrm{cm}^{-1}\right)$ and the $(\mathrm{C}=\mathrm{O})-\mathrm{O}-$ stretching $\left(1050-1095 \mathrm{~cm}^{-1}\right)$. The band at $1200-1275 \mathrm{~cm}^{-1}$, caused by aryl-O of diphenyl ether, involves aryl-O stretch, out-of-phase $\mathrm{C}-\mathrm{O}-\mathrm{C}$ stretching and ring vibrations. An additional important representing band of the molecule is observed at $1125-1205 \mathrm{~cm}^{-1}$ and is related to the $\mathrm{C}-\mathrm{O}$ stretching of the cyanate group $(-\mathrm{O}-\mathrm{C}=\mathrm{N})$. The band at $910-990 \mathrm{~cm}^{-1}$ was assigned to the asymmetric wagging vibrations of the terminal dihalovinyl group, and the band at $810-910 \mathrm{~cm}^{-1}$ was assigned to the deformation vibrations of the cyclopropane ring [32].

In current study, we focused on change in transmission of cypermethrin bonds because according to Beer-Lambert Law "IR transmitted through a solution changes in an inverse logarithmic relationship to the sample concentration" [33].

The results in table5appears clear differences in transmission of cypermethrin bands between zero time and after 14 days of biodegradation. For $P$. aeruginosa, it was clearly note formation new three peaks, which belong to Carbonyl asymmetric, $\mathrm{CH} 2$ deformation in $\mathrm{R}-\mathrm{CH} 2-\mathrm{CN}$ structure and Aryl-O of diphenyl ether. Peak at 1335 belong to N-O symmetric stretch (nitro compound), Peak 1649 belong to $\mathrm{N}$ $\mathrm{H}$ amines group and 1689 belong to $\mathrm{C}=\mathrm{O}$ (carboxylic acid) cannot be detected after 14 days of biodegradation.For $E$. cloacae, We note formationnew four peak which belong to $\mathrm{CH} 2$ deformation in $\mathrm{R}-\mathrm{CH} 2-\mathrm{CN}$ structure, Aryl-O of diphenyl ether, $(\mathrm{C}=\mathrm{O})-\mathrm{O}-$ stretching and Cyclopropane ring, while carbonyl asymmetric band $(\mathrm{C}=\mathrm{O}), \mathrm{C}-\mathrm{H}$ rocks AlKanes group and N-O symmetriv stretch (nitro compounds) can't detected by FTIR spectra after 14 days of treatment with E. cloacae,(Fig 5\& 6).

Changes in peak pattern of cypermethrin under bacterial treatment as compared to zero time were observed in table 5, which indicate to ability of P.aerogenosa and E. cloacae to increase transmission of cypermethrin bands, which indicate that decrease in concentration of compound which composed from these bands according to Beer-Lambert Law. Difference in the FTIR spectrum of zero time and after 14 days of pesticide aqueous solution indicates degradation of the organic bonds of the pesticide, also Stretching in $\mathrm{C}=\mathrm{C}$ chloroalkenes, ring vibration of benzene, $\mathrm{CH} 2$ deformation in $\mathrm{R}-\mathrm{CH} 2-\mathrm{CN}$ structure and $(\mathrm{C}=\mathrm{O})-\mathrm{O}$-stretching in cypermethrin were reported by [34] using Fusariumsp which approve occurrence of biodegradation.

Table 5: Change in transmission of Cypermethrin $100 \mathrm{mg}$ $\mathrm{L}^{-1}$ bands after treatment with Pseudomonas aerogenosaand E. cloacae for 14 days

\begin{tabular}{|c|c|c|c|c|c|}
\hline \multirow{3}{*}{ Band } & \multirow{3}{*}{$\begin{array}{l}\text { Wave } \\
\text { Number }\end{array}$} & \multicolumn{4}{|c|}{ Change in Bands transmission \% } \\
\hline & & \multicolumn{2}{|c|}{ P. aeruginosa } & \multicolumn{2}{|c|}{ E. cloacae } \\
\hline & & $\begin{array}{l}\text { Zero } \\
\text { time }\end{array}$ & Day 14 & $\begin{array}{l}\text { Zero } \\
\text { time }\end{array}$ & Day 14 \\
\hline $\begin{array}{c}\text { Carbonyl } \\
\text { asymmetric } \\
\text { stretching } \\
\end{array}$ & $\begin{array}{c}1720- \\
1740 \mathrm{~cm}^{-1}\end{array}$ & Zero & 30 & Zero & $\begin{array}{c}\text { Not } \\
\text { detected }\end{array}$ \\
\hline $\begin{array}{c}C=C \text { stretching } \\
\text { of the aromatic } \\
\text { rings }\end{array}$ & $\begin{array}{c}1450- \\
1600 \mathrm{~cm}^{-1}\end{array}$ & 24 & 60 & 3 & 94 \\
\hline $\begin{array}{c}\text { CH2 deformation } \\
\text { in } \mathrm{R}-\mathrm{CH} 2-\mathrm{CN} \\
\text { structure }\end{array}$ & $\begin{array}{c}1400-1450 \\
\mathrm{~cm}^{-1}\end{array}$ & Zero & 30 & Zero & 86 \\
\hline $\begin{array}{c}\text { Aryl-O of } \\
\text { diphenyl ether }\end{array}$ & $\begin{array}{c}1200- \\
1275 \mathrm{~cm}^{-1}\end{array}$ & zero & 28 & Zero & 80 \\
\hline $\begin{array}{c}C-O \text { stretching of } \\
\text { the cyanate } \\
\text { group }(-O-C=N)\end{array}$ & $\begin{array}{c}1125-1205 \\
\mathrm{~cm}^{-1}\end{array}$ & 38 & 66 & 6 & 94 \\
\hline $\begin{array}{c}(C=O) \\
-O-\text { Stretching }\end{array}$ & $\begin{array}{c}1050-1095 \\
\mathrm{~cm}^{-1}\end{array}$ & 4 & 39 & Zero & 92 \\
\hline $\begin{array}{c}\text { Terminal } \\
\text { dihalovinyl group }\end{array}$ & $\begin{array}{c}910-990 \\
\mathrm{~cm}^{-1}\end{array}$ & 34 & 68 & 6 & 92 \\
\hline
\end{tabular}

\section{Volume 6 Issue 12, December 2017}




\section{International Journal of Science and Research (IJSR) ISSN (Online): 2319-7064}

Index Copernicus Value (2016): 79.57 | Impact Factor (2015): 6.391

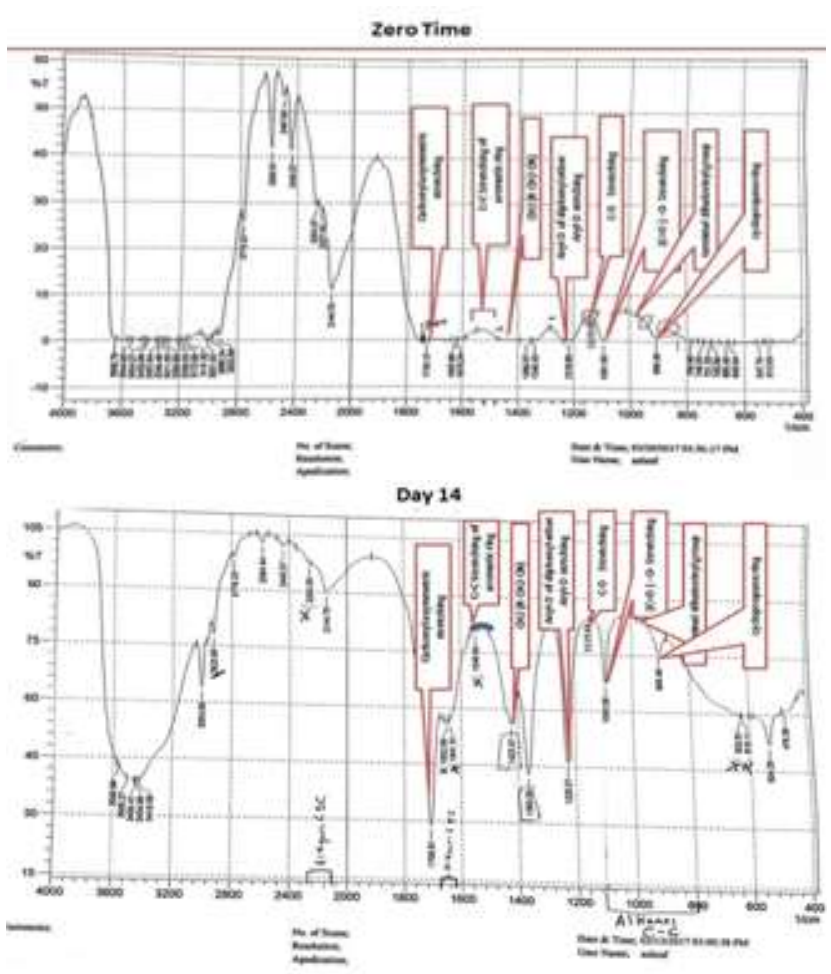

Figure 5: FTIR Results of Cypermethrin $100 \mathrm{mg} \mathrm{L}^{-1}$ after treatment with Pseudomonas aerogenosa for 14 days

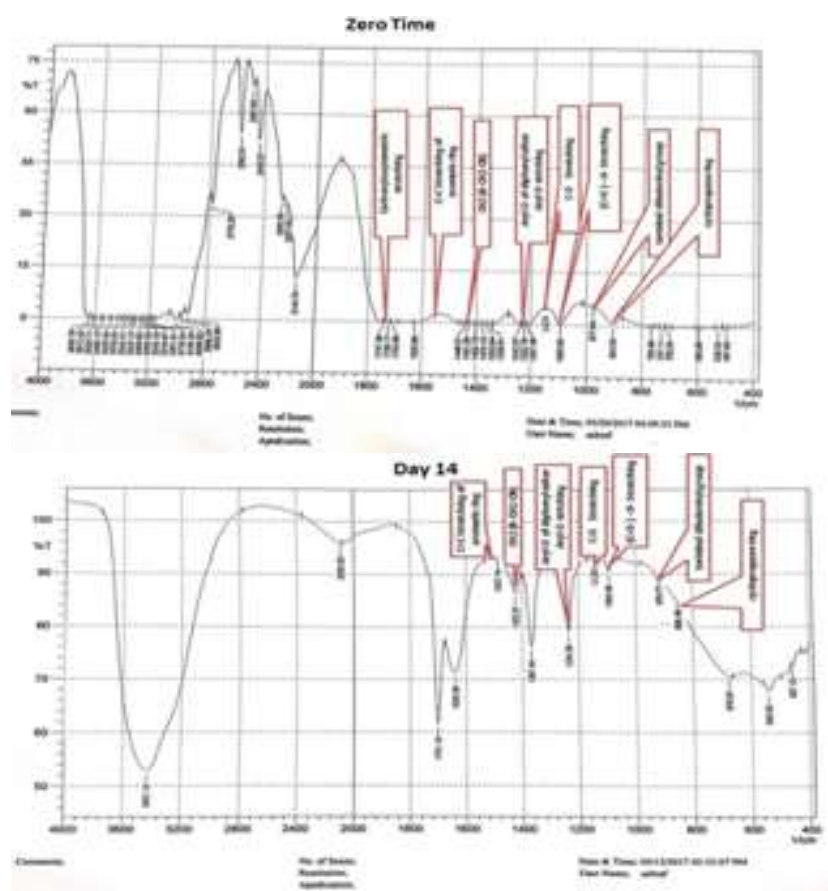

Figure 6: FTIR Results of Cypermethrin $100 \mathrm{mg} \mathrm{L}^{-1}$ after treatment with Enterobacter cloacae for 14 days

\section{GC-MS analysis of biodegraded cypermethrin}

The results of analysis of MMSM containing cypermethrin at concentrations $100 \mathrm{mg} \mathrm{L}^{-1}$ by GC-MS treated separately with each one of two selected isolates showed the presence of cypermethrin and its Intermediate metabolites. These compounds were identified based on their retention time and molecular weight with those of corresponding authentic compounds in the database, also the comparison with standard library of Wiley Registry of Mass Spectral Data version-7 confirmed the matching of mass/charge ratio v/s relative intensity.

The results showed variation in bacterial capacity for degradation of cypermethrin and also variation in intermediate metabolites after 14 day of incubation, the percentage of its degradation were $88 \%$ for $P$. aerogenosa and $94 \%$ for E. cloacaeaccording to biodegradation equation [26].

$\%$ of Biodegradation by $P$. aerogenosa $=\frac{698539-83825}{698539} \times 100=88 \%$

$\%$ of Biodegradation by $E$. cloacae $=\frac{698539-41912}{698539} \times 100=94 \%$

$P$. aeruginosa in current study provides the evidence of efficient degradation pathway of cypermethrin. The bacteria converted cypermetrin into smaller molecular weight compounds which can further be mineralized under natural environmental conditions. Intermediates compounds formed from cypermethrin biodegradation by $P$. aerogenosa are present in table 6.

Table 6: Retention time, Peak area and M. wt. of intermediates metabolites formed from cypermethrin at 100 $\mathrm{mg} \mathrm{L}^{-1}$ biodegraded by $P$. aerogenosa

\begin{tabular}{|c|c|c|c|c|}
\hline NO & $\begin{array}{c}\text { Retention } \\
\text { time }\end{array}$ & $\begin{array}{c}\text { Peak } \\
\text { Area }\end{array}$ & M. wt. & Intermediate metabolites \\
\hline 1 & 4.973 & 120459 & 106 & 1,3-Dimethylbenzene \\
\hline 2 & 9.07 & 448468 & 142 & 2-Methylnonane \\
\hline 3 & 10.966 & 905981 & 94 & Phenol \\
\hline 4 & 10.968 & 816099 & 138 & 4-Hydroxybenzoate \\
\hline 5 & 11.809 & 477692 & 314 & 1,2-Benzenediol, \\
\hline 6 & 12.251 & 3409699 & 188 & 1,8-Cyclotetradecadiyne \\
\hline 7 & 12.522 & 426879 & 138 & 4-Isopropenylcyclohexanone \\
\hline 8 & 15.191 & 1160967 & 148 & 4-Propylbenzaldehyde \\
\hline 9 & 15.43 & 1138664 & 150 & Phenol, M-tert-butyl- \\
\hline 10 & 15.963 & 927213 & 226 & 3-Methylpentadecane \\
\hline 11 & 16.331 & 8487199 & 198 & n-Tetradecane \\
\hline 12 & 16.357 & 1175678 & 164 & 2-Tert-pentylphenol \\
\hline 13 & 16.881 & 600633 & 220 & Butyric acid \\
\hline 14 & 17.751 & 991174 & 186 & 1-Dodecanol \\
\hline 15 & 20.568 & 8882501 & 225 & $\begin{array}{c}\text { a-Hydroxy-3- phenoxy- } \\
\text { benzeneacetonitrile }\end{array}$ \\
\hline 16 & 20.571 & 703191 & 198 & 3-Phenoxy-benzaldehyde, \\
\hline & & & & Isopropyl myristate \\
\hline 17 & 21.749 & 1125347 & 270 & Oleic Acid \\
\hline 18 & 22.787 & 2281725 & 298 & Hexadecanoic acid, methyl ester \\
\hline 19 & 24.895 & 524846 & 282 & Isoamyllaurate \\
\hline 20 & 25.76 & 2099301 & 270 & $\begin{array}{c}\text { Phenyl ester of o-phenoxy } \\
\text { benzoic acid }\end{array}$ \\
\hline 21 & 30.543 & 882673 & 256 & Cypermethrin \\
\hline 22 & 30.801 & 83825 & 415 & $\begin{array}{c}\text { 3-(2,2-dichloroethenyl)-2,2- } \\
\text { cyclopropanecarboxylate }\end{array}$ \\
\hline 23 & 30.943 & 3049045 & 236 & \\
\hline
\end{tabular}

Cypermethrin could be metabolized by $P$. aerogenosa into two major compounds ( $\dot{\alpha}$-hydroxy-3-phenoxy- benzene acetonitrile and 3-(2,2-dichloroethenyl)-2,2-dimethyl cyclopropanecarboxylate). á-hydroxy-3- phenoxy- benzene acetonitrile is unstable and spontaneously transformed to yield 3-phenoxy benzaldehyde [32,35]. 3phenoxybenzaldehyde has antimicrobial activity, but does not affect producing culture and enhances biodegradation in 


\section{International Journal of Science and Research (IJSR) \\ ISSN (Online): 2319-7064}

Index Copernicus Value (2016): 79.57 | Impact Factor (2015): 6.391

soil or media [36]. 3-phenoxybenzaldehyde is transformed into 4-propylbenzaldehyde which again converts to 4hydroxybenzoate. Afterward 4-hydroxybenzoate was metabolized by $P$. aerogenosa to form phenyl ester of ophenoxy benzoic acid. Two intermediate metabolites (3phenoxybenzoic acid and 3-phenoxybenzaldehyde) are the key metabolites of pyrethroids [37].

The GC-MS chromatogram revealed that primary metabolites of degraded cyermethrin by E. cloacae are presented in table 7 .

Table 7: Retention time, Peak area and M. wt. of intermediates metabolites formed from cypermethrin at 100 mg L-1 biodegraded by E. cloacae

\begin{tabular}{|c|c|c|c|c|}
\hline NO & $\begin{array}{c}\text { Retention } \\
\text { time }\end{array}$ & Peak Area & M. wt. & Intermediate metabolites \\
\hline 1 & 4.973 & 100459 & 106 & 1,3-Dimethylbenzene \\
\hline 2 & 8.353 & 24600 & 184 & 11-Methyldodecane \\
\hline 3 & 9.07 & 398345 & 142 & 2-Methylnonane \\
\hline 4 & 10.966 & 8755857 & 94 & Phenol \\
\hline 5 & 10.968 & 816099 & 138 & 4-Hydroxybenzoate \\
\hline 6 & 15.191 & 1160967 & 148 & 4-Propylbenzaldehyde \\
\hline 7 & 15.43 & 988415 & 150 & Phenol, M-tert-butyl- \\
\hline 8 & 15.963 & 907213 & 226 & 3-Methylpentadecane \\
\hline 9 & 16.331 & 8477199 & 156 & Hendecane \\
\hline 10 & 16.357 & 1175678 & 164 & 2-Tert-pentylphenol \\
\hline 11 & 17.853 & 991174 & 197 & 5-methoxy-2-nitrobenzoic \\
\hline 12 & 20.486 & 8882501 & 237 & 3,5-dimethoxybenzamide \\
\hline 13 & 20.537 & 703191 & 181 & 5-aminoisophthalic acid \\
\hline 14 & 21.749 & 1125347 & 270 & Isopropyl myristate \\
\hline 15 & 22.787 & 2273702 & 530 & Phthalic acid \\
\hline 16 & 24.895 & 386691 & 376 & Sulfurous acid \\
\hline 17 & 30.801 & 41912 & 415 & Cypermethrin \\
\hline 18 & 30.892 & 3049045 & 72 & cyclopropanemethanol \\
\hline
\end{tabular}

From the results in table 7 , In the molecular structure of cypermethrin there is an ester bond which is not as firm as other chemical bonds. Previous studies indicated that the first step in the microbial degradation and detoxification of cypermethrin is the hydrolysis of its carboxyl ester linkage [36]. It is evident from GC/MS results that E. cloacae degraded cypermethrin by reductive dechlorination, oxidation or/and hydrolysis to transform to other metabolites. On other hand 3-phenoxybenzoic acid (3-PBA) wasn't detected in the metabolites by GC-MS after 14 days of treatment, while 3-PBA was generally regarded as the major metabolite after hydrolysis of SPs in soil and water [11]. Chen reported that fenvalerate was degraded by hydrolysis of the carboxylester linkage to yield 3-PBA, and then the intermediate was further utilized for bacterial growth by strain ZS-S-01, finally resulted in complete mineralization [17]. So, we speculated that carboxylesterases and oxidoreductases involved in degradation of cypermethrin by E. cloacae, which needed to be testified by further experiments.

Pollution by pyrethroids has become a very important problem in pesticide-treated areas. Currently, one of the major environmental problems is pesticide contamination caused by activities related to agricultural applications. Different mechanical and chemical methods are rarely used to remove pesticides from contaminated fields due to limited efficiency and the expense. Biodegradation is an encouraging process for the treatment of pesticide- contaminated areas due to the rapid and complete mineralization of pesticides. An isolated bacterial strain might be useful for bioremediation of cypermethrin-polluted soil and water environments.

\section{Conclusion}

P. aerogenosa 1 and E. cloacaehave been proved to possess good degradation performance on cypermethrin. The Intermediate metabolites result from two selected isolates were not only proficiently to degrade cypermethrin but also converted the metabolites compound into nontoxic forms.

\section{References}

[1] Ortiz-Hernández, M. L., Sánchez-Salinas, E., OlveraVelona, A., and Folch-Mallol, J. L. (2011). Pesticides in the environment: impacts and their biodegradation as a strategy for residues treatment. Pesticidesformulations, effects, fate. ISBN, 978-953.

[2] EPA. (2006). Cypermethrin: Reregistration Eligibility Decision for Cypermethrin (RED); -HQ-OPP-20050293-0036;U.S. Environmental Protection Agency, Office of Prevention, Pesticides and toxic substance, office of pesticide Programs, U.S. Government Printing Office: Washington, DC.

[3] Weston, D.P., Holmes, R.W., and Lydy, M.J. (2009). Residential runoff as a source of pyrethroid pesticides to urban creeks. Environ. Pollut. 157, 287-294.

[4] Vinodhini, R. and Narayanan, M. (2008). Bioaccumulation of heavy metals in organs of fresh water fish Cyprinuscarpio (Commoncarp). Int. J. Environ. Sci. Tech., 5 (2), 179-182 (4 pages).

[5] Shukla,Y., Yadav, A., and Arora, A. (2002). Carcinogenic and cocarcinogenic potential of cypermethrin on mouse skin. Cancer Lett., 182 (1), 3341 (9 pages).

[6] Javed, M., Majeed, M. Z., Khaliq, A., Arshad, M., and Bakar, M. A. (2015). Review on exposure, absorption and elimination of pyrethroids in humans.

[7] Akbar, S., Sultan, S., and Kertesz, M. (2015). Determination of cypermethrin degradation potential of soil bacteria along with plant growth-promoting characteristics. Current microbiology, 70(1), 75-84.

[8] Wood, T. K., (2008). Molecular approaches in bioremediation. CurrOpinBiotechnol 19:572-578.

[9] You, M., and Liu, X. (2004). Biodegradation and bioremediation of pesticide pollution. Chin J Ecol 23:73-77.

[10] Porto, A. M., Melgar, G. Z., Kasemodel, M. C., and Nitschke, M. (2011). Biodegradation of pesticides, pesticides in modern world-pesticides use and management. [online] http://www.intechopen. com/books/pesticides-in-the-modern-worldpesticidesuse- and-management/biodegradation-ofpesticides.

[11] Suenaga, H., Mitsuoka, M., Ura, Y., Watanable, T., and Furukawa, K. (2001). Directed evolution of biphenyl dioxygenase: emergence of enhanced degradation capacity for benzene, toluene and alkylbenzenes. $J$ Bacteriol.183:5441-5444.

[12] Zhang, C., Wang, S. H., Yan, Y. C. (2011). Isomerization and biodegradation of beta-cypermethrin

\section{Volume 6 Issue 12, December 2017}




\section{International Journal of Science and Research (IJSR) \\ ISSN (Online): 2319-7064}

Index Copernicus Value (2016): 79.57 | Impact Factor (2015): 6.391

by Pseudomonas aeruginosa $\mathrm{CH} 7$ with biosurfactant production. BioresourceTechnol 102:7139-7146.

[13] Lin, Q. S., Chen, S. H., Hu, M. Y., Rizwan-ul-Haq, M., and Yang, L., and Li, H. (2011). Biodegradation of cypermethrin by a newly isolated Actinomycetes HUS-01 from wastewater sludge. Int J Environ SciTechnol 8:45-56.

[14] Chen, S. H., Lai, K. P., Li, Y. N., Hu, M. Y., Zhang, Y.B., and Zeng, Y. (2011). Biodegradation of deltamethrin and its hydrolysis product 3phenoxybenzaldehyde by a newly isolated Streptomyces aureus strain HP-S-01. ApplMicrobiolBiotechnol 90:1471-1483.

[15] Cycon', M., Zmijowska, A., and Piotrowska-Seget, Z. (2014). Enhancement of deltamethrin degradation by soil bioaugmentation with twodifferent strains of Serratiamarcescens. Int J Environ SciTechnol 11:13051316.

[16] Negi, G., PankajSrivastava, A., and Sharma, A. (2014). In situ biodegradation of endosulfan, imidacloprid, and carbendazim using indigenous bacterial cultures of agriculture fields of Uttarakhand, India. Int J Biol Food Vat AgricEng 8(9):935-943.

[17] Chen, S., Lai, K., Li, Y., Hu, M., Zhang, Y., and Zeng, Y. (2011). Biodegradation of deltamethrin and its hydrolysis product 3-phenoxybenzaldehyde by a newly isolated Streptomyces aureus strain HPS- 01. ApplMicrobiolBiotechnol 90:1471-1483. doi:10.1007/ s00253-011-3136-3.

[18] Murugesan, A. G., Jeyasanthi, T., and Maheswari, S. (2010). Isolation and characterization of cypermethrin utilizing bacteria from Brinjal cultivated soil. African Journal of Microbiology Research, 4(1), 010-013.

[19] Thomson, K. S. and Sanders, C. C. (1992). Detection of extended- spectrum $\beta$-lactamases in members of the family Enterobacteriaceae - comparison of the doubledisk and 3- dimensional tests. Antimicrob Agents Chemother 36, 1877-1882.

[20] Shah, K., Shrimali, G., and Mulla, S. (2016). Comparison of Double Disc Diffusion Method and Vitek 2 Compact System to Screen the ESBL Producers in Intensive Care Unit in Hospital. National Journal of Community Medicine, 7(9), 789-791.

[21] Gibb, A. P. and Crichton, M. (2000). Cefpodoxime screening of Escherichia coli and Klebsiella spp. by Vitek for detection of organisms producing extendedspectrum B-lactamases. DiagnMicrobiol Infect Dis 38, 255-257.

[22] Zhang, H., Zhang, Y., Hou, Z., Wang, X., Wang, J., Lu, Z. and Pan, H. (2016). Biodegradation potential of deltamethrin by the Bacillus cereus strain Y1 in both culture and contaminated soil. International Biodeterioration and Biodegradation, 106, 53-59.

[23] Karpouzas, D.G. and Walker, A. (2000). Factors influencing the ability of Pseudomonas putida strains epI and epII to degrade the organophosphate in soil. Soil biology and Biochemistry.32: 1753-1762.

[24] Pankaj, A. S., Gangola, S., Khati, P., Kumar, G., and Srivastava, A. (2016). Novel pathway of cypermethrin biodegradation in a Bacillus sp. strain SG2 isolated from cypermethrin-contaminated agriculture field. 3 Biotech, 6(1).
[25] Anastassiades. M., Lehotay, S.J., Stajnbaher, D., and Schenck, F. J. (2003). Fast and easy multi residue method employing extraction/partitioning and dispersive solid phase extraction for the determination of pesticide residues in produce. J AOAC Int 86:412431 .

[26] Abioye,O. P., Akinsola, R. O., Aransiola, S. A., Damisa, D. and Auta, S. H. (2013). Biodegradation of crude oil by Saccharomyces cerevisiae isolated from fermented Zobo(Locally fermented beverage in Nigeria).Pak .J. bio.scien.16(24):2058-2061.

[27] Garoiaza, H., Berrabaha, M., Elidrissia, A., Hammoutia, B., and Rı'os, A. (2012). Analysis of cypermethrin residues and its main degradation products in soil and formulation samples by gas chromatography-electron impact-mass spectrometry in the selective ion monitoring mode, International Journal of Environmental Analytical Chemistry, 92:12, 1378-1388, DOI: 10.1080/03067319.2011.581365.

[28] Orji, F. A., Ibiene, A. A. and Dike, E. N. (2012). Laboratory scale bioremediation of petroleum hydrocarbon - polluted mangrove swamps in the Niger Delta using cow dung. Malays. J. Microbiol., 8, 219228.

[29] Jilani, S. (2013). Comparative assessment of growth and biodegradation potential of soil isolate in the presence of pesticides. Saudi journal of biological sciences, 20(3), 257-264.

[30] Janssen, P. H., Yates, P. S., Grinton, B. E., Taylor, P. M. and Sait, M. (2002). Improved cultureability of soil bacteria and isolation in pure culture of novel members of the divisions Acidobacteria, Actinobacteria, Proteobacteria, and Verrucomicrobia. Appl. Environ. Microbiol. 68:2391-2396.

[31] Naveenkumar, S., Manoharan, N., Ganesan, S., Manivannan, S. and Velsamy, G. (2010). Isolation, screening in vitri mutational assessment of indigenous soil bacteria for enhanced capability in petroleum degradation .International journal of environmental sciences, vol. 1(4): 0976 - 4402.

[32] Lin-Vien, D., Colthup, N. B., Fateley, W. G. and Grasselli, J. G. (1991). The handbook of Infrared and Raman Frequencies of Organic Molecules; Academic Press: London.

[33] Ricci, R. W., Ditzler, M., and Nestor, L. P. (1994). Discovering the Beer-Lambert Law. J. Chem. Educ, 71(11), 983.

[34] Kaur, P., Sharma, A., and Parihar, L. (2015). In vitro study of mycoremediation of cypermethrincontaminated soils in different regions of Punjab. Ann Micobiol. doi:10.1007/s13213-015-1033-1.

[35] Xiao, Y., Chen, S., Gao, Y., Hu, W., Hu, M., and Zhong, G. (2015). Isolation of a novel betacypermethrindegradings train Bacillus subtilis BSF01 and its biodegradation pathway. Appl. Microbiol. Biotechnol. 99,2849-2859.doi: 10.1007/s00253-0146164-y.

[36] Chen, S, Hu, M, Liu, J, Zhong, G, Yang, L, Rizwan-ulhaq, M, and Han, H. (2011). Biodegradation of betacypermethrin and 3-phenoxybenzoic acid by a novel Ochrobactrum lupine DG-S-01. Journal of Hazardous Materials. , 187(1), 433-440. 


\section{International Journal of Science and Research (IJSR) \\ ISSN (Online): 2319-7064}

Index Copernicus Value (2016): 79.57 | Impact Factor (2015): 6.391

[37] Laffin, B., Chavez, M., Pine, M. (2010). The pyrethroid metabolites 3-phenoxybenzoic acid and 3phenoxybenzyl alcohol do not exhibit estrogenic activity in theMCF-7 human breast carcinoma cell line or Sprague-Dawley rats. Toxicology 267:39-44.

Volume 6 Issue 12, December 2017

www.ijsr.net

Licensed Under Creative Commons Attribution CC BY 